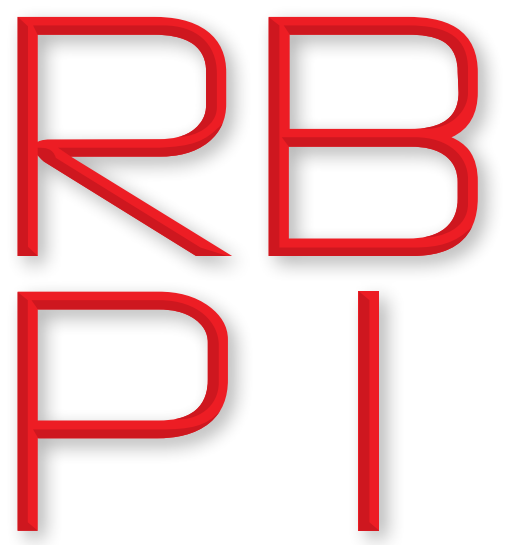

Revista Brasileira de Política Internacional ISSN 1983-3121

http://www.scielo.br/rbpi

\section{Monica Herz}

Instituto de Relações Internacionais, Pontifícia Universidade Católica do Rio de Janeiro - PUC-Rio, Rio de Janeiro - Rio de Janeiro, Brazil (herz@puc-rio.br).

ORCID ID:

orcid.org/0000-0003-2061-2699

\section{Layla Dawood}

Universidade do Estado do Rio de Janeiro, Departamento de Relações Internacionais, Rio de Janeiro - Rio de Janeiro, Brazil (layladawood@hotmail.com).

in ORCID ID:

orcid.org/0000-0003-0708-1627

\section{Victor Coutinho Lage}

Universidade Federal da Bahia, Programa de Pós-Graduação em Relações Internacionais, Salvador - Bahia, Brazil (victorclage@gmail.com).

iD ORCID ID orcid.org/0000-0002-0998-3619

\section{Copyright:}

- This is an open-access article distributed under the terms of a Creative Commons

Attribution License, which permits unrestricted use, distribution, and reproduction in any medium, provided that the original author and source are credited.

- Este é um artigo publicado em acesso aberto e distribuído sob os termos da Licença de Atribuição Creative Commons, que permite uso irrestrito, distribuição e reprodução em qualquer meio, desde que o autor e a fonte originais sejam creditados.

\section{The Defense-Development Nexus: Brazilian Nuclear Policy under the Workers' Party Administrations}

DOI: http://dx.doi.org/10.1590/0034-7329201800105

Rev. Bras. Polít. Int., 61(1): e005, 2018

\section{Abstract}

Focusing on the Workers' Party administrations (2003-2016), we claim that, among other crucial ideas and interpretations, the framing process of the Brazilian nuclear program by the ruling elites can be understood through the notion of a mendes-pimentelense nexus. To support that claim, Section II discusses the developmentalist thinking in Brazil. Section III, presents a historical overview of the role of the armed forces in issues of national development, defense, and nuclear technology. Section IV proposes the notion of a defense-development nexus as an analytical approach to the issue. Finally, some concluding remarks are pointed out.

Keywords: Defence policy; development; Brazil, nuclear policy.

Received: May 29, 2017

Accepted: November 23, 2017

\title{
Introduction
}

$\tau$ $\mathrm{n}$ this text, focusing on the Workers' Party administrations (20032016), we claim that, among other crucial ideas and interpretations, the framing ${ }^{1}$ process of the Brazilian nuclear program by the country's ruling $^{2}$ elites can be understood through the notion of a defensedevelopment nexus. Our analysis shows that the arguments of the ruling elites ${ }^{3}$ in support of nuclear technology development are inserted in a broader context of association between development and nation building. Moreover, the specific role of the armed forces for the

1 For more information on the concept of framing, please check: Goffman (1974) and Crawford (2002).

2 For more information on the theory of elitism, see: lbertoni (1987).

3 We understand the ruling elite as those in control of strategic decision-making processes in society. The ruling elite changes constantly and includes actors that have access to economic, military, political, and cultural resources that enable a significant impact in the way a society is governed. The competition between various regional or functional elites, clearly present during the democratic phase of Brazilian history, will not be analysed here, although it is of core relevance to this debate. We do not deal here with the huge and profoundly relevant literature that engages critically with the development and security policies implemented but the Workers Party administrations. 
development of the nuclear sector in Brazil can be understood through the analysis of the arguments advanced by these actors in terms of their contribution for the promotion of the broader development of the nation. It is not our purpose to provide an evaluation of the effectiveness of the development strategies or the wisdom of defense procurement decisions; instead, we aim at analyzing the arguments presented by the ruling elites for their choices of both defense and development policies. In addition, it is important to clarify that this article does not propose an overall explanation of the Brazilian nuclear policies during the Worker's Parties administrations ${ }^{4}$. The tension between the Brazilian governments and the nonproliferation regime has often been discussed in terms of the elements of adaptations to the nuclear regime and forms of resistance, such as the refusal to sign the additional Protocol. The framing of the country's policies toward nuclear technology includes concerns with its insertion in the international system in terms of autonomy, - crucially the maintenance of the right to develop nuclear technology for peaceful uses - and the enhancement of its position in the systemic hierarchy of power and the perception of threat in the South Atlantic ${ }^{5}$.

Although we acknowledge the importance of those other arguments and facts in interpreting Brazil's nuclear policies, in this article, we focus on the embeddedness of the nuclear policy within the broader framing of development goals both historically and during the Workers Party tenure.

The link between development and the construction of the nation has assumed different facets, but remains relevant for our understanding of nuclear programs in the world, particular in the developing world. According to José Goldemberg (2001), the technological innovation related to nuclear energy had two concomitant impacts: on the one hand, the possibility of a peaceful application of nuclear energy was seen as a form of compensation for the horror of the attacks in Japan; on the other hand, it was understood at the time that nuclear energy would be a cheaper and less pollutant alternative to generate power, which would contribute to the autonomy of a country:

Many developing countries saw in nuclear energy a "passport to modernity" and began either developing reactors internally, which was the case of India, or purchasing them on a turnkey basis, which was the case of Brazil and Iran under the Sha's regime (Goldemberg 2011, 103).

It is crucial to consider how the Brazilian elites have argued about the role of the state in the promotion of development in order to fully understand the conditions for the creation and development of Brazil's nuclear policies. Hence, to understand its importance for the ruling elites, one must be aware of how this technology is inscribed not only in their security thinking, but also in the way the development thinking is formulated.

4 This text follows previous works (Herz et al. 2016; 2017) and is inscribed in a larger project (out of which a book will soon be published) in which we analyse the way Brazilian ruling elites have formulated, conducted and mainly how they framed (and justified) the Brazilian nuclear program.

5 The relation between the project to build nuclear propelled submarines and security in the South Atlantic is discussed in Herz et al. (2017). The defence development nexus will provide an additional interpretation of the refusal to sign the Additional Protocol and the skepticism regarding the proposals for the multilateral enrichment of uranium, since the framing of nuclear policy in terms of development will allow us to understand the Brazilian position regarding the preservation and advancement of its access to technology vis a vis the nuclear governance regime. 
In order to advance this point, the text is divided into three main sections following this introduction. We begin by situating the developmentalist thinking in Brazil, since it is important for at least three reasons: (1) for the understanding of the role of the state for the project of development in Brazil; (2) for the understanding of the scenario in which the nuclear issue came to acquire relevance within the political agenda; and (3) to the analysis of the rereading of the development project by the Workers' Party. We, then, present a historical overview of the role of the armed forces in issues of national development, defense, and nuclear technology. This role is reviewed as conceived by the ruling elites. Drawing on the two previous sections, section IV proposes the notion of a defense-development nexus as an analytical approach to the nuclear issue under the Workers' Party government. Finally, some concluding remarks are pointed out.

\section{The role of the state in development promotion: nuclear technology as a path to national development and autonomy}

After the Second World War, in line with many other countries that saw themselves as latecomers to industrial development, the Brazilian ruling elites articulated a project that established a link between nation building and development ${ }^{6}$. According to the desenvolvimentista project, industrialization would contribute to overcome underdevelopment and poverty and this could only happen with the guidance and intervention of the state. The middle classes, and the military and industrial sectors became increasingly involved in building this view of the country's history. As Ricardo Bielschowsky (2000) has showed in detail, since the 1930s, as industrialization became a central concern to academic and the public debates in Brazil, "developmentalism" became a key concept in the controversies regarding the articulation between the public and the private sectors ${ }^{7}$.

Two distinct moments in Brazilian history epitomize the concern with development in terms of industrial and technological rapid modernization: the Juscelino Kubitschek years (1956-1960) and the military dictatorship (1964-1985). The Kubitschek years are remembered in this regard for the construction of a new national capital, Brasilia, and the creation of the automobile industry, while the military dictatorship invested in infrastructure such as dams, roads, and ports. In both periods, we witness an intense participation of the state in the attempt to foster economic development. It is in this scenario that the investment in the nuclear sector gained more resonance on the political agenda.

Though the inception of systemic research in the nuclear field dates back to the 1930's in Brazil, during the Juscelino Kubitschek administration (1956-1960), the investment in nuclear power was especially encouraged. In a message to the Congress in the first year of his administration, Kubitschek said that "the era of atomic power plants, for whose use the country should prepare

\footnotetext{
6 For the relation between building "national identity" and development in Brazil, see Chilcote (2014).

7 As Bielschowsky (2000) discusses at length, there has never been a consensus regarding the kind of intervention that the state should be in charge of - a debate that is far from being unique to Brazil, for sure. Our purpose here, however, is not to approach the controversies surrounding that topic, but to present the notion of development put forward by Lula's government. For a historical perspective on Brazilian development in the postwar era, see Diniz (2011) and Ioris (2014).
} 
now" was approaching ${ }^{8}$. The development of nuclear energy was included in his so-called Goals Plan (Plano de Metas), the fundamental developmental program at that time.

Between 1951 and 1963, several institutions related to nuclear research were created in Brazil. The list includes: the Conselho Nacional de Desenvolvimento Cientifico e Tecnológico (CNPq, National Research Council, 1951); Comissão de Exportação de Materiais Estratégicos (CEME, Commission on the Export of Strategic Materials1952); Comissão Nacional de Energia Nuclear (CNEN, National Commission of Atomic Energy, 1954) of CNPq; which was replaced two years later by the CNEN (1956); Instituto de Pesquisas Energéticas e Nucleares (IPEN, Institute of Radioactive Research, 1953); Instituto de Engenharia Nuclear (IEN, the Institute of Atomic Energy,1956); Instituto de Radioproteção e Dosimetria (IRD, Instituto de Engenharia Nuclear (IEN, Institute of Radiation Protection and Dosimetry, 1960); and the Institute of Nuclear Engineering (1963). Furthermore, a Nuclear Engineering Course was introduced in 1954 at the Instituto Militar de Engenharia (IME, Military Institute of Engineering and the Esclola Nacional de Engenharia (National School of Engineering) ${ }^{9}$. After Vice President João Goulart (1961-1964) assumed office, he announced the decision to build the first nuclear power plant in Brazil in 1963, as well as the establishment of state monopoly over the research and exploration of nuclear material and its processing industry.

Another important development was the inauguration of a nuclear program under the responsibility of the Navy in the 1970's. The objective of the new program was to control the nuclear fuel cycle and to build a nuclear reactor in order to advance the construction of a Brazilian nuclear propelled submarine (Correa 2012). Since the inception of the program, the design and construction of a nuclear propelled submarine was framed by naval officers and Brazilian politicians as both a military need as well as a means to promote national development.

Claiming that the ratification of international and regional nuclear governance agreements could hamper Brazil's nuclear technology development and, therefore, the overall development in the county, the military administrations refused to sign international agreements within the field of nuclear nonproliferation.

On the other hand, in 1974, the Ernesto Geisel administration (1974-1979) signed the Protocol of Brasília, which was the basis for the establishment in the following year of the Agreement on Cooperation in the Field of Peaceful Uses of Nuclear Energy, according to which there would be a transfer of technology related to the uranium enrichment cycle (Lima 2013).

During João Batista Figueredo's administration (1979-1985), the Brazilian nuclear program experienced a strong deceleration, as a result of economic hardship in Brazil. In 1983, the government decided to postpone the construction of the nuclear power plants Angra 2 and Angra $3^{10}$. Nonetheless, in 1980 Brazil started a process of rapprochement with Argentina, with the

8 This passage is quoted in Motta (2010,118). We take this opportunity to mention that one of the major initiatives of recording and analysing Brazil's Nuclear Policy was named the "Historical Memory and Strategic Nuclear Energy in Brazil", pursued under an agreement between the CPDOC/FGV and FINEP. Marly Motta coordinated this project until 2011.

9 This list draws on the works cited so far, as well as on Brandão (2008).

10 See Lima (2013). 
Cooperation Agreement for the Development and Application of Peaceful Uses of Nuclear Energy, which aimed to provide for the exchange of information between both countries with respect to their nuclear programs. Such rapprochement would intensify in the next administration ${ }^{11}$.

During the administration of the first democratic government after the transition from military dictatorship - the José Sarney administration (1985-1990) -, the Navy Technological Center was created including its headquarters in the city of Sáo Paulo and a research center located in the city of Iperó. In 1987, President Sarney officially declared that Brazil dominated the complete cycle of uranium enrichment; a landmark for any nuclear program. Meanwhile, signaling the peaceful nature of the Brazilian nuclear program, the Constitution of 1988 included a ban on the use of nuclear energy for non-peaceful purposes.

During the administration of Fernando Henrique Cardoso (1995-2002), the historic ratification of the NPT occurred in 1998, which raised a lot of controversy among diplomats and academics. In terms of nuclear development, Cardoso's administration established nuclear cooperation agreements with India ${ }^{12}$ and the United States in 1996, visited Russian nuclear facilities, and expanded the cooperation with Argentina, which was focused on technological assistance to Angra 2.

As we can see from this brief historical overview, the project for the investment in nuclear technology is embedded in a broader concept of development and the role of the state in development promotion. It was also suggested that the armed forces had a special role in the development of nuclear technology in Brazil. We argue in the next section that this role can be better understood in connection to the military elite's argument that the armed forces has a protagonist role in nation-building and development promotion.

\section{Brazilian Armed Forces, the defense industry and national development}

The argument for the positive association between defense expenditures and growth is generally based on a concept known as "spin off". It is claimed that a country's defense industrial base operates as a leading sector, providing spin offs to the rest of the economy ${ }^{13}$. Many scholars and decision makers claim that defense expenditures can promote growth in developing countries if they are used to forge infrastructures such as roads, airports, and communication networks. It is also argued that defense expenditures can foster growth by providing training and education for the less privileged part of the developing countries' population who did not have opportunities elsewhere (Sandler and Hartley 1995, 187, 197, 201-203) ${ }^{14}$.

11 For more details on the approach with Argentina during this period, see Vargas (1997), Fonrouge (1995), Mallea (2013a; 2013b; 2013c) and Carpes (2006).

12 Two years after the Agreement for Cooperation in Peaceful Uses of Nuclear Energy with India, Brazil terminated it as a retaliation against a series of nuclear explosions that India conducted weeks before the termination of the treaty.

13 Examples of this phenomenon are the transference of technological discoveries from military to civilian aircraft and of laser technology to ophthalmic surgery.

14 The Economics of Defence field has produced a series of studies to investigate the association between defence spending and economic growth. Nonetheless, the results found by these studies are not unequivocal. According to Benoit (1978), large shares of GDP devoted to defence have promoted growth in more than 40 developing countries. In turn, many scholars have questioned Benoit's results and have reached diametrical 
Accordingly, Brazilian Navy's officials and scholars specialized in naval history have highlighted the historic role of the Navy in promoting the development of the country. For instance, in a book that commemorates the $50^{\text {th }}$ anniversary of the partnership between the Brazilian Navy (Marinha Brasileira) and the Universidade de Sáo Paulo (USP, State University of São Paulo ), it is argued that the history of naval engineering and naval construction in Brazil is very much intertwined with the history of the Brazilian Navy itself.

The Navy has been a huge advocator of the nationalization of technology. Admiral Álvaro Alberto Mota e Silva (founder and first president of CNPq) defended the thesis of specific compensation, whereby the transfer of technology would be a compensation for all transactions of minerals of strategic interest. His positions were challenged by other important actors, in particular the Minister of Foreign Affairs at the time, João Neves da Fontoura, and the Export of Strategic Materials Commission created in 1952 under the Ministério das Relaçôes Exteriores (Ministry of Foreign Affairs) ${ }^{15}$.

The Navy sought to contribute to Brazil's economic development by fostering close ties with the civilian academic sector. In 1956, through an agreement between the Navy and the USP, the Naval Engineering School was created in the Polytechnic School (Escola Politécnica (POLI-USP)) of the same University to reach two main objectives: 1) to train naval engineers to develop projects and coordinate civil and military vessels repair; and 2) to consolidate a technological culture that would stimulate the national naval industry. The predominant belief was that the autonomy of the national industry would only be reached if national engineers were trained inland (Saes and Cytrynowicz 2007, 29) ${ }^{16}$.

According to Vice-Admiral Armando de Senna Bittencourt:

After the agreement signed with USP, the Navy gradually nationalized the graduate engineering courses for its officers. Instead of creating its own military institute, it took advantage of the university resources and helped to improve those resources (quoted in Saes and Cytrynowicz 2007, 30).

On the other hand, the Brazilian Navy's involvement with the economic development of the country is very much related to its contribution to the birth and consolidation of the naval industry in Brazil. For many years, this industrial sphere depended heavily on the demand from the Navy and other agencies of the public sector. In turn, the rise of the Brazilian naval industry influenced the development of other industrial sectors to attend this industry's demand for naval parts and raw materials. The naval industry is primarily devoted to the production of new naval vessels; for that

opposite conclusions after applying different methodologies (Sandler and Hartley 1995). There are scholars who are sceptical regarding the occurrence of spin offs in developing economies. This is due to the participation of foreign firms in the national defence industrial bases of developing countries, diminishing the probability of transference of technology to other sectors of the national economy (Dagnino 2004; 2010). 15 See Brandão (2008) for an analysis of the defeat of the admiral's position.

16 Nowadays, the Department of Naval Engineering at USP is a consolidated research institute that offers both undergraduate and graduate courses. The professionals trained by this department work in various economic activities such as: naval construction industry (including shipyards, naval parts sector), intercontinental transportation of commodities, minerals and manufactured products, cabotage transportation, support operations for the offshore petroleum platforms, ocean mining and maritime exploration of biological resources. Those professionals also work on the development of naval technology to provide for maritime and fluvial defence. For more, see http://www.poli.usp.br/pt/apoli/departamentos/pnv.html (Escola Politécnica [n.d.]). 
purpose, it mobilizes various other industries in complex engineering projects. Thus, it is an area where spin offs can be potentially observed (see Goularti Filho 2009; and Saes and Cytrynowicz 2007).

The concern with nationalization and the goal to diminish the military dependence on the U.S. were very clear for high ranking Brazilian Navy's officers from the 1950s to the 1970s (Amaral 2013 $)^{17}$. During the 1970s, class Niterói frigates and class Inhaúma corvettes were built in Brazil. The latter were the first combat vessels projected nationally since 1890 . This project was designed by the Brazilian Navy Division for Naval Engineering with the assistance of the German firm Marine Technik. The nationalization index of the coverts was 50\% (Telles 2001). During the first half of the 1980s, Brazil signed a contract with a German consortium for the construction of three submarines in Brazil and one in Germany. The contract provided for the transference of the technology to build submarines and the offer of materials and services.

Modern vessels were built in Brazil throughout the decades of 1980 and 1990. For that to happen, the Brazilian industrial matrix had to produce naval parts following very rigorous demands such as high resistance to shocks, silent operation, non-production of toxic gases in case of fire and restrictions related to weight and size. Therefore, according to Telles (2001), the naval industry contributed to the technological progress of the country, notably with regards to the protocols to guarantee industrial quality. The Navy also sought to help the country's development fomenting the nationalization of various components of the vessels such as batteries for submarines and control system for machines, among other things (Bittencourt 1995 quoted in Telles 2001, 198).

In 1976, Othon Luiz Pinheiro da Silva (who was a Captain-of-Corvette at the time, from the Engineers Corps) was sent by the Navy to the United States, more precisely to the Massachusetts Institute of Technology (MIT), to be trained in nuclear engineering. In 1978, he presented a report about a possible nuclear submarine project. From that moment and onwards, the Captain-of-Corvette Othon da Silva would become a major figure in the history of the Brazilian Nuclear Program, particularly regarding the relation between such history and both the nuclear submarine project and the Programa Paralelo (Parallel Program) ${ }^{18}$.

Finally, Cosme Degenar Drumond - a technician educated at the National Museum and currently employed by the defense industry in Brazil - argues that other branches of the armed forces also contributed to national development. For instance, he states that the creation of a major aircraft industry in Brazil was only possible due to the existence of Instituto Tecnológico da Aeronáutica (ITA), which provided the necessary research and personnel to indigenously develop

17 The American influence over the Brazilian Navy was exerted academically, regarding access to equipment, doctrine and strategic and organizational matters. Since 1922, there was an American Naval Mission established in Brazil to cooperate with the Brazilian Navy in matters related to military doctrine, strategy, organizational procedures, and training. That mission exerted especial influence on the Brazilian Naval War Program, directed to high rank naval officers. In addition, in the 1930's, the Americans offered technical assistance in the development of contra-torpedoes class Mahan (named class Marcílio Dias in Brazil): those were the first modern vessels built inland. This influence was increased during the Second World War and soon after it. This was due to the fact that Brazil could buy, at symbolical prices, American naval equipment which was used during that war. In 1952, a military cooperation agreement was signed between Brazil and the U.S.: due to this agreement, the acquisition of American military equipment was facilitated. Nonetheless, American assistance was also provided to Chile and Argentina in South America and this might have influenced Brazil's reach for European naval equipment in the 1960s (Amaral 2013).

18 See Martins Filho (2011) for details of the history of Brazil's nuclear submarine program. 
technology and to enable international partnerships to project and produce aircrafts in Brazil. In addition, Drumond states that the demands from the Força Aérea Brasileira (FAB, Brazilian Air Force) for the mechanical industry to produce more resistant pieces had a direct and positive impact on the national civilian industry, such as the production of buses (Drumond 2014, 86). In turn, Empresa Brasileira de Aeronáutica (Embraer) - an enterprise founded in 1969 with private and public resources, initially controlled by the federal government and later privatized in 1994 - has become one of the major global producers of aircrafts, adding value to Brazil's exports.

After presenting the Brazilian elite's historical claims connecting the defense industry to the role of the military and development, the next section will discuss how this link was expressed under the Workers' Party administrations.

\section{The defense-development nexus and the nuclear issue under the Workers' Party administrations}

As we saw in the previous sections, Brazilian nuclear policy can also be analyzed in the context of a wider development project. Or, more precisely, Brazilian nuclear policy demands the understanding of how the state, the defense sector, and development claims are inseparable.

Considering that the formulation of Brazilian foreign policy also can be examined as an aspect of broader national objectives regarding state planning, including first and foremost its search for national development (Lessa et al. 2009), we observe how the nuclear sector expresses close links between foreign policy and national development. With that in mind, in what follows our aim is first to briefly present the perspective on development underpinning the Workers' Party government, focusing on the features that are relevant to our discussion in this text. After that, we discuss the defense industry in relation to what we call a defense-development nexus during the same period ${ }^{19}$.

\section{The Workers' Party perspective on development and the nuclear issue}

During the Workers' Party tenures, development was sought through a focus on the internationalization of a group of Brazilian firms and a new relationship with selected sectors of the economy. Between 2003 and 2008, a growth strategy was put in place geared towards the stimulation of investment, as well as the generation of employment, income, and social inclusion in face of a favorable international environment. At the same time, the aim was to maintain the macroeconomic stability acquired during the previous government.

Lula's government inherited the tradition of "developmentalism" briefly presented in section II - the nuclear policy being one of the areas where this is clearly expressed. In the Workers' Party coalition program launched for the 2002 election campaign, one reads "three basic pillars" on

19 It is not our purpose in this text to advance a critical engagement with the Workers' Party developmental and defence policies, but to analyse the arguments presented by the ruling elites. This, however, seems to be a crucial step towards any critical assessment of these policies. 
the infra-structural sector: (a) "a new conception of planning and development", where "public planning is a state action, essentially so and non-transferable"; (b) the "reconstruction of cities and urban development"; and (c) "energy for development", including here an energy plan comprising nuclear generation (see Coligação Lula Presidente 2002, 53-4). More specifically, in a section devoted to "energy", one reads that the government will "reestablish the strategic planning that existed in the electric sector and that was abandoned with the attempt to implement a market model" $(2002,65)$. The proposed "integrated planning" includes nuclear generation, besides oil, natural gas, hydroelectricity, alternative sources; and, to that aim, "the public sector should be mobilized and the private sector, encouraged" $(2002,65)$.

In the coalition program launched for the 2007-2010 term, development remains a central concern, including the energy sector, although the nuclear issue is not specified (see Garcia [2006]). In both programs, development is conceived and justified in terms of its economic, social, and environmental aspects, therefore in a perspective that is broader than an exclusively economic and industrial one. This is one of the major differences when one contrasts "new developmentalism" to the first articulations of the "developmentalist" thinking from the $1930 \mathrm{~s}^{20}$.

Aloizio Mercadante Oliva, who has taken part in all of Lula's electoral campaigns and became one of the most important names during his tenures, submitted a $\mathrm{PhD}$ dissertation in 2010 entitled "The bases of new developmentalism [novo desenvolvimentismo] in Brazil: an analysis of Lula's government (2003-2010)" (Oliva, 2010). There, he highlights that "new developmentalism" is "substantially different" from "the old national-developmentalism prevailing in the past" (Oliva $2010,17)$. At the same time, however, Oliva claims that the conception of "development" under Lula's administration and "developmentalist" thinking have important connections with each other: "[i]n using the concept of 'new developmentalism' to understand the recent period of Brazilian development, we are, for sure, establishing a dialogue with the rich theoretical experience of classic developmentalist thinkers, especially with Celso Furtado" (Oliva 2010, 9).

Moreover, the Lula administration has constantly conceived its development program as a counterpoint to "neoliberalism", as both programs mentioned make clear, as well as Oliva (2010), where one reads that "the new project of national development" gathered "the main political forces that resisted neoliberalism and the interruption of the construction of Brazil" (2010, 5, 17). It is not our purpose here to discuss the similarities and differences between Lula's developmental policy and "neoliberal" or " old developmentalist" projects, nor to assess and evaluate the effectiveness of the implementation of the development policy planned. Rather, we want to expose how the policy is conceived.

Besides the connection between the concept of "development" under Lula's tenures and the developmentalist thinking tradition in Brazil, it is also important to situate "new developmentalism"

20 For more on "national-developmentalism", see Bielschowsky (2000) and Ioris (2014). The concept of "new developmentalism" has been also used since the 2000s by a group of thinkers, such as Luiz Carlos Bresser-Pereira, as a normative and theoretical contribution to political economy (see, for instance, Bresser-Pereira 2015). Although it bears some similarities to Lula's administration development policy, it is not plausible to say that this policy is underpinned by "new developmentalism" as Bresser-Pereira and others conceive it; actually, both Oliva (2010, 11-2) and Bresser-Pereira $(2015,344-51,370)$ have made that point in different ways. For more on "new developmentalism" as it is theoretically understood by Bresser-Pereira and others, see for instance Ten Theses on New Developmentalism (2012); Cepêda (2012); and Silva (2013). 
within a broader moment in Latin America and in the emerging countries in which alternative strategies of "development" re-entered the stage of the academic and public debates worldwide in face of a problematization of the "neoliberal consensus" in economic thinking and in approaches to the relation between the state and the market in the development process (see Erber 2009; Erber 2011; Diniz 2011; Silva 2013; Gomide and Boschi 2016) ${ }^{21}$. More precisely, the legitimation sought for this conception is linked to its proposition as an alternative to the prevailing conceptions of "development", very often characterized as "neoliberal". In "new developmentalism", The state is conceived "as a key actor in the generation of a developmental dynamics" (Gaitán and Boschi 2016, 475; see also Diniz 2011; Gomide, 2016), but its action is also defended in terms that go beyond the economic dimension emphasized by classic "developmentalism". It is said to include a social and the environmental dimension as well.

Erber's $(2009 ; 2011)$ analysis seems useful for us here to further specify how Brazilian nuclear policy is understood under the concept of development articulated during Lula's administration. He argues that Lula's administration has combined two "development conventions". One is devoted to the implementation of norms and organizations that guarantee the correct functioning of the markets. Following this convention, the market is conceived as a legitimate institution "in charge of organizing and conducting economy and society" (Erber, 2009, 123).

Coexisting with, and subordinated to, the first convention, Fabio Erber $(2009 ; 2011)$ identifies a "neodevelopmentalist" convention. Expressed, for instance, in the Programa de Aceleração do Crescimento (PAC, Program of Growth Acceleration) and the Politica de Desenvolvimento Produtivo (PDP, Policy of Productive Development) ${ }^{22}$. According to Erber (2011), one of the pillars of this convention is the investment in infra-structure (for instance, energy), conducted mainly by state and private enterprises funded by the Banco Nacional de Desenvolvimento Econômico e Social (BNDES, Brazilian Development Bank) and the federal state $(2011,46)^{23}$. This pillar is connected to the coalition between contractors and the federal government ${ }^{24}$.

The neodevelopmentalist convention has important implications for Brazilian nuclear policy. Firstly, an association between development and the creation of a competitive and as autonomous as possible nuclear sector is clearly established. In the website of the Ministério do Desenvolvimento, Indústria e Comércio (MDIC, Ministry of Development, Industry and Commerce), for instance,

21 To be clear, we are referring here to the consensus regarding "neoliberal" macroeconomic policies (which, by the way, has never ceased to encounter many resistances from different perspectives). A whole different discussion would be whether "neoliberalism" can be restricted to its economic dimension and whether the 2008 Financial Crisis replaced it by a variation of some "Keynesianism". We will not deal with that here.

22 PAC was launched in 2007 and had its second phase in 2011. See: pac.gov.br. (Ministério do Planejamento [n.d.]). PDP was launched in 2008 and, in 2011, was integrated into the Plano Brasil Maior (Greater Brazil Plan). See http://www.abdi.com.br/paginas/pdp.aspx. (Agência Brasileira de Desenvolvimento Industrial [n.d.]).

23 Erber (2011) identifies five pillars in this convention, and reminds us that some of them represent an update of the "ancient developmentalist proposal" (2011, p.46). According to Carlos Santana (2016), the emphasis on the "capacity of coordination of the central government on the energetic infra-structure was one of the priorities of the new coalition in 2003 [in Brazil]" (2016, 250), being part, therefore, of the wider redefinition of the state role in the promotion of national development.

24 Odebrecht was the national construction firm hired to build the naval shipyard for the nuclear submarine (see Ministry of Defense website. Available at: https://www1.mar.mil.br/prosub/parceiros). (Ministério da Defesa [n.d.]). Together with other mayor firms such as Andrade Gutierrez and Queiroz Galvão, Odebrecht was also involved with the assembling of the third nuclear power reactor to be built in Brazil, Angra 3 (see http://www.eletronuclear.gov.br/Not\%C3\%ADcias/NoticiaDetalhes.aspx?NoticiaID=1445) (Eletrobras-Eletronuclear 2014). 
it is stated that the nuclear energy sector is part of the Policy of Productive Development with the following goals: (a) "to consolidate the country as an important producer of nuclear fuel"; (b) "to participate, in a competitive way, in the supply of electric energy in the country"; and (c) "to guarantee competence in all the stages of the fabrication of equipments, the commissioning of nuclear facilities and the production of fuel elements" 25 . Secondly, the development of the Brazilian nuclear reactor is directly associated with the Program of Growth Acceleration. For instance, the construction of Angra 3 (planned to be the next Brazilian nuclear power reactor) was announced as an important part of the Program in 2011 (see Sassine 2011); in January 2016, the Minister of Defense, Aldo Rebelo, affirmed that the inclusion of the Reator Multipropósito Brasileiro (RMB, Brazilian Multipurpose Research Reactor) under the PAC was "a positive factor to the Navy Nuclear Program” (see Ministério da Defesa, 2016).

In its positioning on the global governance mechanisms related to nuclear technology, Brazilian officials have constantly restated the importance the country ascribed to nuclear technology for national development. Overall, within different international fora, Brazilian officials have expressed the country's position in favor of the discussions and debate on the proposals of multilateral approaches to nuclear fuel-cycle taking place in the scope of the International Atomic Energy Agency $(\text { IAEA })^{26}$. For instance, in the 2009 IAEA General Conference, the Brazilian representative to the organization stated that "Brazil sees merit in the ideas advanced by many, including the Director General, that ultimately all enrichment and reprocessing activities, without discrimination, should be placed under some kind of multilateral control" 27 . This position is invariably accompanied by the insistence on the importance of nuclear programs to national development.

25 These goals can be read at the presentation of the Policy of Productive Development, available at: http://www.abdi.com.br/Estudo/ Apresenta\%C3\%A7\%C3\%A3o\%20PDP\%20Completa\%20-\%2012-05-2008.ppt (Agência Brasileira de Desenvolvimento Industrial [2008].

26 The multilateral approaches to the nuclear fuel-cycle have a long history, going back at least to the Baruch Plan (1946), the Atoms for Peace (1953) and the establishment of the IAEA (1957). Nowadays, there is an ongoing debate about different proposals for multilateral nuclear approaches. Many proposals and reports were delivered more recently. Some of them are the following. In 2006, the IAEA Director General Mohamed ElBaradei gave a statement on A New Framework for the Nuclear Fuel Cycle. (Statement by the IAEA Director General Dr. Mohamed ElBaradei to the Special Event on Nuclear Fuel Cycle of the IAEA General Conference) (El Baradei 2006). In 2007, one has the German proposal (IAEA Document INFCIRC/704) (International Atomic Energy Agency 2007a), the Austrian food-for-thought paper (IAEA Document INFCIRC/706) (IAEA 2007b) and the Russian paper on the Establishment, Structure and Operation of the International Uranium Enrichment Center. (IAEA Document INFCIRC/708) (IAEA 2007c). In 2008, the German proposal was updated and it was delivered a German proposal for a Multilateral Enrichment Sanctuary Project (See IAEA Document INFCIRC/727) (IAEA 2008a); in the same year, there was a shared report of Germany, Netherlands and Great Britain, that followed the conference Nuclear Fuel Supply: Challenges and Opportunities, held in Berlin in April 2008 (IAEA Document INFCIRC/728) (IAEA 2008b); in this event on Berlin, the IAEA Director General ElBaradei gave another important speech on Nuclear Energy: The Need for a New Framework (Statement by the IAEA Director General Dr. Mohamed El Baradei to the International Conference on Nuclear Fuel Supply) (El Baradei 2008). In 2009, there was the Austrian proposal (IAEA Document INFCIRC/755) (IAEA 2009) and the Board of Governors approved a plan to edify a nuclear fuel bank in Russia. In addition to that, there are projects for the establishment of international uranium enrichment centers and multilateral fuel-banks as well as institutional initiatives designed for promoting multilateral cooperation on nuclear fuel-cycle technology under a non-proliferation framework, for instance the International Framework for Nuclear Energy Cooperation, developed by the Global Nuclear Energy Partnership (IFNEC). United States, China, France, Japan and Russia are the founding members of the Global Nuclear Energy Partnership. In 2013, IFNEC had 32 participant countries, 31 observer countries and 3 intergovernmental observers. Brazil's current status is of an observer country. See World Nuclear Association (International Framework for Nuclear Energy Cooperation 2012). To the full list of membership, see http://www.ifnec.org/About/Membership.aspx (The International Framework for Nuclear Energy Cooperation [n.d.]).

27 Statement by Brazil at the $53^{\text {rd }}$ General Conference of the IAEA (Guerreiro 2009). For another statement on that, see Statement by Brazil to the $3^{\text {rd }}$ Session of the Preparatory Committee to the $8^{\text {th }}$ NPT Review Conference - Cluster III (Soares 2008). 
In sum, in its stance regarding global governance mechanisms related to nuclear technology the Workers' Party administration reinforced how the peaceful use of nuclear energy must be defended. This position is integrated in the wider claim that nuclear energy is fundamental to national development.

From what has been said so far, three things come to the fore: (1) the way the Lula administration recuperated a certain developmentalist thinking tradition in conceiving the role of the state in the promotion of national development; (2) the "new" aspects ascribed to this thinking tradition, emphasizing the social and environmental aspects of development; and (3) the importance ascribed to nuclear policy in the developmental policy under Workers' Party administrations. Now, we turn to the discussion of the defense sector connection with national development and the continuing central role occupied by the Navy in the nuclear and development policies.

\section{Defense industry}

The connection between nation building, the defense sector, and development is noticeable in the Workers' Party thinking. It is crucial to understand that the support for defense investment is cast in terms of its association with development, although other features also can be considered, such as perceptions of threat. Thus, the defense-development nexus is a wider cognitive framing within which nuclear policy is encompassed. In fact, during the Workers' Party administrations, the armed forces role in the promotion of development was reinforced, justifying new investments in the defense industry and the reaffirmation of the Navy as one of the central pillars of the Brazilian nuclear program. For instance, in the abovementioned dissertation, Oliva (2010) highlighted that the "new developmentalism" is inseparable from a "new insertion of the country in the international scenario" (480). Oliva stressed that "it is necessary to establish a synergy between diplomatic persuasion (foreign policy) and strategic deterrence (defense policy)" (2010, 483); moreover, he continues, "we cannot renounce to have a well-equipped and well-trained conventional force and to develop an efficient defense industry that promotes technological innovation and economic development" (2010, 484).

This link between defense and development was strongly reaffirmed during a circle of debates promoted by the Ministry of Defense from 2003 to 2004 . The results of those debates were published at the Ministry website under the name of "Pensamento brasileiro sobre defesa $e$ segurança" ${ }^{28}$. The discussions revealed the existence of a new lobby in Brazil formed by military members, businessmen, journalists, and scholars who support the revitalization of the Brazilian Defense Industry (BDI). The main argument advanced by what Dagnino (2010) refers to as the "Revitalization Net" is that the increase in defense investments will lead to economic and social development. Members of the "Revitalization Net" also claim that a renewed defense industry in Brazil would satisfy the armed forces military demands, reducing imports and possibly increasing

28 For more information, check the Brazilian Ministry of Defence at: http://www.defesa.gov.br/arquivos/colecao/brasil.pdf (Pinto at al. 2004). 
Brazilian exports in this area (Dagnino 2010, 9-11) 29 . Supporters of these arguments refer to the need to return to a "golden era" which supposedly took place in the 1980's, when Brazil was a major exporter of defense products.

This argument supporting a positive link between defense investment and development was reflected on the 2008 National Defense Strategy which openly stated the goal to modernize the armed forces, connecting this objective to the revitalization of the Brazilian Defense Industry. In the introduction to the document, the link is straightforward:

[...] the national defense strategy is inseparable from the national development strategy. The latter motivates the former. The former protects the latter. Each reinforce the reasons for the other [...] Once protected, Brazil will have the capacity to build its own development model". As for the link between defense promotion and the national defense industry: "the second structuring feature [of the NDS] refers to the reestablishment of the national defense material industry in order to assure that the fulfillment of the armed forces need for equipment will be supported by technologies of national domain (Brasil 2008, 1).

In what refers to the nuclear technology role in the promotion of national development, the document states that "the nuclear sector is of strategic value. On its own nature, it transcends the limits between development and defense" (Brasil 2008, 33).

It is important to clarify that we are not saying that the defense sector arguments concerning development were translated into actual results in terms of the development of the nation. Regarding the discussion above, it is our purpose neither to discuss whether the defense industry was completely modernized nor whether the effective developmental achievements or failures during the Workers Party administrations were caused by investments in defense ${ }^{30}$.

Nonetheless, the arguments connecting defense and development accompanied the revitalization of the Brazilian nuclear program, noticeably the rebirth of the nuclear submarine program. Investment in the nuclear submarine project resumed after the Workers' Party came to

29 Dagnino (2010) disputes each of the arguments advanced by the Revitalization Net. Simply put, he does not believe that a revitalized defence industry will provide economic benefits to the country. He states that the cause of the Brazilian Defence Industry decline in the end of the 1980's was not only a matter of decreased investments, but also of decreased demand for Brazilian defence products in face of the end of the Iran-Iraq war. In addition, he highlights that Brazil was always a major importer of defence goods, even during the period of increased Brazilian defence exports. This is the case because the armed services demanded high technology material which were not available domestically. Dagnino claims that this reality will endure since firms involved in the Brazilian defence sector are multinationals which tend not to nationalize P\&D. This article is not aimed at verifying if the spill off phenomenon actually happened. In contrast, we argue that the spill off claim is important to the extent that it makes certain investments possible to the detriment of others.

30 In fact, according to the official website of the Ministry of Defence, during the administrations of presidents Lula and Dilma, although the absolute defence spending increased from 25,8 billion BR $\$$ in 2003 to 76,9 billion in 2014, there was a decrease in what regards the percentage of the GDP devoted to defence (from 1,46\% to 1,39\%). This means that the potential of producing spin offs was not considerably increased. In addition, it is important to notice that, historically, a great portion of the Brazilian defence spending goes to personnel payment. In 2014, 72\% of the total defence budget was spent with personnel, $15 \%$ with operational costs and $11 \%$ with investments (Information available at: http://www.defesa.gov.br/arquivos/orcamento_financas/despesas_2015.jpg) (Ministério da Defesa [2015]). Therefore, despite the renewal of claims of promoting development through investments in defence and in spite of the absolute increase in defence spending numbers, these phenomena did not necessarily translate into capability improvement or modernization during the PT administrations. 
power with the election of Luis Inácio Lula da Silva and the Roussef administration continued to further develop it (Martins Filho 2011, 2012).

In 2005, Admiral Othon Luiz Pinheiro da Silva was appointed head of Eletro nuclear, which was a clear indicator of the renewed relevance of the Brazilian nuclear projects, since Admiral Othon is considered one of fathers of the Brazilian nuclear programme and was tasked in the 1980s to build a nuclear reactor. Another important development took place in 2007, when President Lula visited the Navy's nuclear facilities in Aramar and announced that he would designate one billion Brazilian Reais to revitalise the programme (Kassenova 2014) ${ }^{31}$.

The revitalization of the program, as we saw, was framed through a group of arguments which connected defense and development. The understanding of these arguments is necessary, even if not sufficient, to analytical efforts concerned with this revitalization.

\section{Concluding remarks}

This article tried to understand the articulation of Brazil's nuclear policy under the Workers' Party administrations, highlighting a defense-development nexus present in the ruling elites' arguments for the revitalization of major nuclear programs. We claim that the Lula and Dilma governments recuperated and resignified a certain notion of "developmentism". Like its predecessor, "neodevelopmentism" continued to defend a central role for the state in the promotion of national development. At the same time, it also claimed to be supplementing the "old developmentalism" with social and environmental concerns.

In this context, political elites argued for the revitalization of major nuclear projects (such as the nuclear propelled submarine and the construction of a third nuclear power reactor), connecting nuclear technology to the broader promotion of national development and to the state institutions role in the promotion of development. As we saw, private and public actors were involved in the revitalization of major nuclear projects. Major contractor firms where hired by the federal government and this was framed as a means to promote national development. In addition, the central role of the Navy and of former naval officers (such as Admiral Othon Pinheiro da Silva) in this process needs to be highlighted. More importantly, the arguments advanced by the Brazilian Navy's representatives were in tune with a "neodevelopmentalist" logic articulated by the federal administrations.

In this text, we were concerned with the analysis of the conjunction of arguments advanced by the political elites, the Navy and the private sector, since it is crucial for an understanding of Brazil's nuclear policy in the 2000's. This analysis is also important for further assessments and critical engagements with Brazilian Nuclear Policy and, more generally, its place in the defense-development nexus in the Worker's Party administration.

31 The fulfilment of the nuclear submarine project, as well as the assembling of Angra 3 have been recently impacted by the current economic crisis and the corruption scandals involving the private constructors and some leading figures of Brazil's nuclear program. 


\section{References}

Agência Brasileira de Desenvolvimento Industrial. Inovar e investir para sustentar o crescimento.

[Brasília, DF]: [2008]. Accessed February 19, 2018. http://www.abdi.com.br/Estudo/

Apresenta\%C3\%A7\%C3\%A3o\%20PDP\%20Completa\%20-\%2012-05-2008.ppt

Agência Brasileira de Desenvolvimento Industrial. "Plano Brasil Maior.", accessed February

19, 2018. http://www.abdi.com.br/paginas/pdp.aspx

Amaral, M. H. S. "O poder pelo mar: a indústria de construção naval militar no Brasil a partir da política desenvolvimentista de Juscelino Kubitschek (1956-1961).” Master diss., Fundação Getúlio Vargas, 2013.

lbertoni, E. A. Mosca and the Theory of Elitism. Oxford; New York: B. Blackwell, 1987. Benoit, E. "Growth and defense in developing countries." Economic Development and Cultural Change 26, no. 2 (1978): 271-80. doi: https://doi.org/10.1086/451015.

Bielschowsky, R. Pensamento econômico brasileiro: o ciclo ideológico do desenvolvimentismo. Rio de Janeiro: Editora Contraponto, 2000.

Brandão, R. V. M. "O negócio do século: o acordo de cooperação nuclear Brasil-Alemanha." Master thes., Universidade Federal Fluminense, 2008.

Brasil. Decreto no. 6.703, de 18 de dezembro de 2008. "Aprova a Estratégia Nacional de Defesa, e dá outras providências." Diário Oficial da União, December 19, 2008. http:// www.planalto.gov.br/ccivil_03/_ato2007-2010/2008/Decreto/D6703.htm

Bresser-Pereira, L. C. A construção politica do Brasil: sociedade, economia e Estado desde a Independência. 2a edição. São Paulo: Editora 34, 2015.

Carpes, M. "A política nuclear brasileira no contexto das relaçóes internacionais contemporâneas: domínio tecnológico como estratégia de inserção internacional.” Master thes., Pontifícia Universidade Católica do Rio de Janeiro, Rio de Janeiro, 2006.

Cepêda, V. A. "Inclusão, democracia e novo-desenvolvimentismo: um balanço histórico." Estudos Avançados 26, no. 75 (2012): 77-90. doi: http://dx.doi.org/10.1590/S0103-40142012000200006.

Chilcote, R. H. Intellectuals and the search for national identity in twentieth-century Brazil. Cambridge, U.K.: Cambridge University Press, 2014. doi: https://doi.org/10.1017/ CBO9781107785298.

Crawford, N. C. Argument and change in world politics: ethics, decolonization, and humanitarian intervention. Cambridge, U.K.: Cambridge University Press, 2002.

Coligação Lula Presidente. Programa de Governo 2002: um Brasil para todos. 2002. http:// novo.fpabramo.org.br/uploads/programagoverno.pdf

Correa, F. G. "Projeto do submarino nuclear brasileiro: ciência, tecnologia, cerceamento e soberania nacional." Revista Maritima Brasileira 132, no. 7-9 (2012): 11-5.

Dagnino, R. "Sobre a revitalização da indústria de defesa brasileira." In As forças armadas e o desenvolvimento científico e tecnológico do pais, organized by J. R. A. Pinto, A. J. 
R. Rocha, and R. D. P. Silva, 81-128. Brasília, D.F.: Ministério da Defesa, 2004. Pensamento brasileiro sobre defesa e segurança. http://www.defesa.gov.br/arquivos/ colecao/cientecnol.pdf

Dagnino, R. A indústria de defesa no governo Lula. São Paulo: Expressão Popular, 2010. Diniz, E. "O contexto internacional e a retomada do debate sobre desenvolvimento no Brasil contemporâneo (2000/2010).” Dados 54, no. 4 (2011): 493-531. doi: http://dx.doi.org/10.1590/S0011-52582011000400001.

Drumond, C. D. Indústria de defesa do Brasil: história, desenvolvimento, desafios. Guarulhos: ZLC, 2014.

El Baradei, M. Statement at the Special Event on the Nuclear Fuel Cycle. Viena: 2006 https://www.iaea.org/newscenter/statements/nuclear-energy-need-new-framework

El Baradei, M. Nuclear Energy: The Need for a New Framework. Viena: 2008 https://www. iaea.org/newscenter/statements/nuclear-energy-need-new-framework

Eletrobras-Eletronuclear. "Consórcios Angras 3 e Uma 3 assinam contratos para iniciar montagem eletromecânica da Usina Angra 3.” last modified September 3, 2014, http:// www.eletronuclear.gov.br/Not\%C3\%ADcias/NoticiaDetalhes.aspx?NoticiaID=1445

Erber, F. S. "As convençóes de desenvolvimento no governo Lula: um ensaio de economia política." Revista de Economia Politica 31, no. 1 (2011): 31-55.

Erber, F. S. "Convenções do Desenvolvimento". Insight Inteligência, no. 44 (2009): 108-130. Accessed February 19, 2018. http://insightinteligencia.com.br/pdfs/44.pdf

Escola Politécnica. "PNV - Engenharia Naval e Oceânica." Accessed February 19, 2018. http://www.poli.usp.br/pt/a-poli/departamentos/pnv.html

Fonrouge, M. F. V. "A convergência nuclear Brasileiro-Argentina: agente da integração e fator de estabilidade regional.” Master thes., Pontifícia Universidade Católica do Rio de Janeiro, Rio de Janeiro, 1995.

Gaitán, F., and R. R. Boschi. "Estado, atores predominantes e coalizóes para o desenvolvimento: Brasil e Argentina em perspectiva comparada”. In Capacidades estatais em paises emergentes: o Brasil em perspectiva comparada, edited by A. Á. Gomide, and R. R. Boschi, 473-506. Brasília, D.F.: Ipea, 2016.

Garcia, M. A., coord. Lula presidente: programa de governo 2007/2010. [2006]. http://csbh. fpabramo.org.br/uploads/Programa_de_governo_2007-2010.pdf

Goffman, I. Frame analysis: an essay on the organization of experience. Cambridge, Mass: Harper \& Row, 1974.

Goldemberg, J. “News and Views: Perspectives for Nuclear Energy in Brazil After Fukushima”. Brazilian Journal of Physics 41, (2011): 103-6, 2011. doi: http://dx.doi.org/10.1007/s13538-011-0027-0.

Gomide, A. Á. “Capacidades estatais para políticas públicas em países emergentes: (des) vantagens comparativas do Brasil." In Capacidades estatais em paises emergentes: o Brasil em perspectiva comparada, edited by A. Á. Gomide, and R. R. Boschi, 15-50. Rio de Janeiro: IPEA, 2016. 
Gomide, A. Á., and R. R. Boschi, eds. Capacidades estatais em paises emergentes: o Brasil em perspectiva comparada. Rio de Janeiro: Ipea, 2016.

Goularti Filho, A. "História econômica da construção naval no Brasil: formação de aglomerado e performance inovativa." Paper presentes at the $37^{\text {th }}$ Encontro Nacional de Economia, Foz de Iguaçu, Paraná, Dezember 8-11, 2009.

Guerreiro, A. Statement by the Permanente Representative of Brazil, Ambassador Antonio Guerreiro, to the $53^{\text {rd }}$ General Conference of the IAEA. [n.p.]: IAEA, 2009. https://www. iaea.org/About/Policy/GC/GC53/Statements/brazil.pdf

Herz, M., L. Dawood, and V. C. Lage. "Brazilian nuclear policy during the Workers' Party years." The Nonproliferation Review 23, no. 5-6 (2016): 559-73. doi: https://doi.org/10.1080/10736700.2016.1246100.

Herz, M., L. Dawood, and V. C. Lage. "A Nuclear Submarine in the South Atlantic: The Framing of Threats and Deterrence." Contexto Internacional 39, no. 2 (2017): 329-350. doi: http://dx.doi.org/10.1590/s0102-8529.2017390200007.

International Atomic Energy Agency. INFCIRC/704. [n.p.]: IAEA, 2007a. https://www.iaea. org/publications/documents/infcircs/communication-received-resident-representativegermany-iaea-regard-german-proposal-multilateralization-nuclear-fuel-cycle

International Atomic Energy Agency. INFCIRC/706. [n.p.]: IAEA, 2007b. https://www.iaea. org/publications/documents/infcircs/communication-received-federal-minister-europeanand-international-affairs-austria-regard-austrian-proposal-multilateralization-nuclearfuel-cycle

International Atomic Energy Agency. INFCIRC/708. [n.p.]: IAEA, 2007c. https://www.iaea. org/publications/documents/infcircs/communication-received-resident-representativerussian-federation-iaea-establishment-structure-and-operation-international-uraniumenrichment-centre

International Atomic Energy Agency. INFCIRC/727. [n.p.]: IAEA, 2008a. https://www. iaea.org/publications/documents/infcircs/communication-dated-30-may-2008received-permanent-mission-federal-republic-germany-agency-regard-german-proposalmultilateral-enrichment-sanctuary-project

International Atomic Energy Agency. INFCIRC/728. [n.p.]: IAEA, 2008b. https://www. iaea.org/publications/documents/infcircs/communication-dated-30-may-2008received-permanent-mission-federal-republic-germany-agency-regard-german-proposalmultilateral-enrichment-sanctuary-project

International Atomic Energy Agency. INFCIRC/755. [n.p.]: IAEA, 2009. https://www. iaea.org/publications/documents/infcircs/communication-dated-26-may-2009received-permanent-mission-austria-agency-enclosing-working-paper-regardingmultilateralisation-nuclear-fuel-cycle

Ioris, R. R. Transforming Brazil: a history of national development in the postwar era. New York: Routledge: 2014. 
Kassenova, T. Brazil's nuclear kaleidoscope: An evolving identity. Washington: Carnegie Endowment for Peace, 2014.

Lessa, A. C., L. F. Couto, and R. S. Farias. "Política externa planejada: os planos plurianuais e a ação internacional do Brasil, de Cardoso a Lula (1995-2008)." Revista Brasileira de Politica Internacional 52, no. 1 (2009): 89-109. doi: http://dx.doi.org/10.1590/S0034-73292009000100005.

Lima, M. R. S. The Political economy of brazilian foreign policy: nuclear energy, trade and Itaipu. Brasília, D.F.: Fundação Alexandre Gusmão, 2013.

Mallea, R. "The First Attempt at Argentine-Brazilian Nuclear Cooperation and the Argentine Response, 1967-1972." Nuclear Proliferation International History Program, 2013a. http://www.wilsoncenter.org/publication/the-first-attempt-argentine-braziliannuclear-cooperation-and-the-argentine-response

Mallea, R. "From the Indian Bomb to the Establishment of the First Brazil- Argentina Nuclear Agreement (1974-1980).” Nuclear Proliferation International History Program, 2013b. https://www.wilsoncenter.org/publication/the-indian-bomb-to-the-establishmentthe-first-brazil-argentina-nuclear-agreement-1974

Mallea, R. "Resolving the Dilemma of Nuclear Mistrust: From Foz do Iguacu to the Constitution of ABACC (1985-1991)." Nuclear Proliferation International History Program, 2013c. http://www.wilsoncenter.org/publication/resolving-the-dilemmanuclear-mistrust-foz-do-iguacu-to-the-constitution-abacc-1985-1991

Martins Filho, J. R. "O projeto do submarino nuclear brasileiro.”

Contexto Internacional 33, no. 2 (2011): 277-314, 2011.

doi: http://dx.doi.org/10.1590/S0102-85292011000200002.

Martins Filho, J. R. “The Brazilian Submarine Project.” Paper presented at the Brazil and Global Nuclear Order workshop, co-hosted by Carnegie Endowment for International Peace and Fundação Getúlio Vargas. [n.p.], May 15, 2012.

Ministério da Defesa. "Infográfico." [2015], accessed February 19,2018.http://www.defesa. gov.br/arquivos/orcamento_financas/despesas_2015.jpg.

Ministério da Defesa. "Programa Nuclear da Marinha tem grande importância para a defesa, diz Aldo", last modified January 21, 2016, http://www.defesa.gov.br/noticias/18038programa-nuclear-da-marinha-tem-grande-importancia-para-a-defesa-diz-aldo

Ministério da Defesa. "Programa de Desenvolvimento de Submarinos." Accessed February 19, 2018. https://www1.mar.mil.br/prosub/parceiros

Ministério do Planejamento. “Sobre o PAC.”, accessed February 18, 2018.

Motta, M. “As peças do quebra-cabeça: Rex Nazaré e a política nuclear brasileira.” História Oral 13, no. 2 (2010): 115-35.

Oliva, A. M. "As bases do novo desenvolvimentismo no Brasil: análise do governo Lula (2003-2010).” PhD diss., UNICAMP, 2010.

Pinto, J. R. A., A. J. R. Rocha, and R. D. P. Silva, orgs. O Brasil no cenário internacional de 
defesa e segurança. Brasília, D.F.: Ministério da Defesa, 2004. v. 2, Pensamento Brasileiro sobre defesa e segurança. http://www.defesa.gov.br/arquivos/colecao/brasil.pdf

Saes, A. M., and R. Cytrynowicz. Cinquentenário do convênio entre a Marinha do Brasil e a Universidade de São Paulo: a criação do curso de Engenharia Naval na Escola Politécnica. São Paulo: Narrativa, 2007.

Sandler, T., and K. Hartley. The economics of defense. Cambridge, U.K.: Cambridge University Press, 1995.

Santana, C. H. V. "Políticas de infraestrutura energética e capacidades estatais nos BRICS.” In Capacidades estatais em paises emergentes: o Brasil em perspectiva comparada, edited by A. Á. Gomide, and R. R. Boschi, 219-58. Rio de Janeiro: Ipea, 2016.

Sassine, V. "Brasil nuclear: incentivos para a construção de usinas.", last modified Jane 7 , 2011, http://www.defesanet.com.br/tecnologia/noticia/1319/Brasil-Nuclear---Incentivospara-a-construcao-de-usinas/

Silva, S. S. "Novo desenvolvimentismo, governo Lula e dilemas de uma concepção de desenvolvimento inspirada em elementos do capitalismo anglo-saxão." In Novas Interpretaçôes desenvolvimentistas, organized by S. B. Castro, 451-528. Rio de Janeiro: Centro Celso Furtado, 2013.

Soares, L. F. M. Statement by the Head of the Delegation of Brazil, Ambassador Luiz Filipe de Macedo Soares Geneva: 2008. https://unoda-web.s3-accelerate.amazonaws.com/ wp-content/uploads/assets/WMD/Nuclear/NPT2010Prepcom/PrepCom2008/ delegates\%20statements/Brazil\%20(modified).pdf

Telles, P. C. S. História da construção naval no Brasil. Rio de Janeiro: Fundação de Estudos do Mar, 2001.

“Ten theses on new developmentalism.” Brazilian Journal of Political Economy 32, no. 2 (2012): 336-9.

The International Framework for Nuclear Energy Cooperation. "Membership." accessed February 19, 2018. https://www.ifnec.org/ifnec/jcms/g_5196/membership Vargas, E. V. "Átomos na integração: a aproximação Brasil-Argentina no campo nuclear e a construção do MERCOSUL.” Revista Brasileira de Politica Internacional 40, no. 1: 1997: 41-74. doi: http://dx.doi.org/10.1590/S0034-73291997000100003. 